Territorios 41 / Bogotá, 2019, pp. 245-270

ISSN: 0123-8418

ISSNe: 2215-7484

\title{
Lugares sagrados y altares simbólicos en Medellín*
}

Sacred Places and Symbolic Altars in Medellin

Lugares sagrados e altares simbólicos em Medellín

\section{Nora Margarita Vargas Zuluaga** \\ Hilderman Cardona Rodas ${ }^{\star \star}$}

Recibido: 15 de mayo de 2018

Aprobado: 26 de marzo de 2019

Doi: http://dx.doi.org/10.12804/revistas.urosario.edu.co/territorios/a.6811

Para citar este artículo:

Vargas Zuluaga, N. M., \& Cardona Rodas, H. (2019). Lugares sagrados y altares simbólicos en Medellín. Territorios, (41), 245-270. Doi: http://dx.doi.org/10.10.12804/revistas.urosario.edu.co/territorios/a.6811

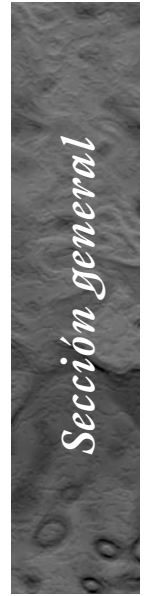

* Este artículo se circunscribe a las investigaciones Educar en tiempos de convivencia: de las corpo-realidades en el aula (Universidad de Medellín y Universidad de Antioquia, 2018-2020) y Derecho a la ciudad, estudio geoetnografico sobre el impacto social de las iniciativas de desarrollo urbano en la ciudad de Bogotá y Medellín (Universidad de Medellin y Universidad de los Andes, 2016-2018).

* Docente de tiempo completo de la Facultad de Ciencias Sociales y Humanas de la Universidad de Medellín. Licencia en Formación Estética de la Universidad Pontificia Bolivariana y magister en Desarrollo Sustentable de la Universidad de Lanús de 
Palabras clave

Estéticas populares, arte chicano, espacios sagrados/espacios profanos, fotografía.

Keywords

Popular aesthetics, Chicano art, sacred / profane space, photography.

Palavras-chave

Estéticas populares, arte chicana, espaços sagrados/espaços profanos, fotografia.

\section{territarias 41}

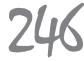

\section{RESUMEN}

Se invita a recorrer lugares donde se evidencian procesos interculturales en los cuales se difuminan fronteras del pasado y el presente, lo rural y lo urbano, así como las de lo sagrado y lo profano. Al reconocer la singularidad estética que habita la ciudad de Medellín se pusieron en relación objetos heteróclitos, en lo que puede catalogarse como ritualidades contemporáneas y, en este sentido, relacionar las estéticas que se han denominado chicanas con los escenarios íntimos de significación en la ciudad de Medellín, las cuales se reflejan en cartografías visuales de creencias que evocan íconos religiosos cristianos muy conectados con la cultura campesina antioqueña. Se presenta y analiza una serie de fotografías seleccionadas con el fin de establecer posibles conexiones a nivel de las estructuras simbólicas entre estos altares encontrados en el barrio Bello Oriente y algunas manifestaciones del arte chicano caracterizado por el uso de símbolos religiosos, políticos y culturales que reflejan problemas sociales y de identidad en el espacio urbano.

\section{ABSTRACT}

We make an invitation to visit places where intercultural processes are evident and borders of past and present, rural and urban, as well as the sacred and profane blur. Recognizing the aesthetic singularity that inhabits Medellin city, we were able to relate heteroclite objects in what is recognizable as contemporary rituals and, in this sense, the aesthetics referred to as Chicanas with the intimate scenes of meaning in Medellin, which reflect in visual cartographies of beliefs that evoke Christian religious icons intimately connected with Antioquia's peasant culture. We present a series of photographs to establish connections at the level of the symbolic structures between the Bello Oriente neighborhood altars and some Chicano art manifestations characterized by the use of religious, political, and cultural symbols that reflect social and identity problems in urban scenarios.

\section{RESUMO}

Se convida a recorrer lugares onde evidenciam-se processos interculturais nos quais se diluem fronteiras do passado e o presente, o rural e o urbano, assim como as do sagrado e o profano. Ao reconhecer a singularidade estética que habita a cidade de Medellín permite pôr em relação objetos heteróclitos, no que pode reconhecer-se como ritualidades contemporâneas e, neste sentido, relacionar as estéticas que se têm denominado chicanas com os cenários íntimos de significação na cidade de Medellín, as quais se refletem em cartografias visuais de crenças que evocam ícones religiosos cristãos muito conectados com a cultura camponesa de Antioquia. Se apresenta e analisa uma serie de fotografias selecionadas com o objetivo de estabelecer possíveis conexões no nível das estruturas simbólicas entre estes altares encontrados no bairro Bello Oriente e algumas manifestações da arte chicana caraterizada pelo uso de símbolos religiosos, políticos e culturais que refletem problemas sociais e de identidade no espaço urbano. 


\section{Introducción}

El presente texto tiene como base la compilación de un conjunto de experiencias en niños y jóvenes participantes en un proceso pedagógico realizado en el barrio Bello Oriente, en el marco de una intervención social de ese sector de la comuna 3 de $\mathrm{Me}$ dellín. Fue un trabajo colaborativo en el cual los participantes de los talleres casual e independientemente de las intenciones de dicho proyecto propiciaron una serie de reflexiones mientras se hacían registros fotográficos, incluso en algunas oportunidades ellos fueron quienes indicaron querer ser fotografiados. Estas imágenes producto de la experiencia etnográfica personal estuvieron archivadas sin aparente sentido hasta este momento, es decir, estas fueron el resultado de una experiencia de recorrido por la comuna 3 de Medellín (barrio Bello Oriente), tomadas a modo de juego en momentos de interacción cotidiana con los jóvenes que acudían a aquellos talleres, que hoy son reveladas tras descubrir en ellas ciertos rasgos comunes que dan cuenta de una estética que se asemeja en sus estructuras simbólicas a otras identificadas en latitudes y contextos distantes que dan cuenta de procesos culturales aparentemente disímiles como es el caso de lo chicano, en una lógica de hibridez cultural como la plantea Nestor García Canclini (1990):

Así como no funciona la oposición abrupta entre lo tradicional y lo moderno, tampoco lo culto, lo popular y lo masivo están donde nos habituamos a encontrarlos [estética simbólica]. Es necesario desconstruir esa división en tres pisos, esa concepción hojaldrada del mundo de la cultura, y averiguar si su hibridación puede leerse con las herramientas de las disciplinas que los estudian por separado: la historia del arte y de la literatura, que se ocupan de lo "culto"; el folclor y la antropología, consagrados a lo popular; los trabajos sobre comunicación, especializados en la cultura masiva. Necesitamos ciencias sociales nómadas capaces de circular por las escaleras que comunican esos pisos. O mejor: que rediseñen los planos y comuniquen horizontalmente los niveles (pp. 9-10).

En Colombia varias épocas históricas se enfrentan, se ignoran y conviven: la gran ciudad, lo rural, el arte culto, el arte popular aseptizado por los museos, lo popular que se resiste, el bricolaje etc. En Medellín, la población de los barrios llamados populares o laderas del valle ha experimentado el desplazamento y la invasión, que manifiesta fenómenos de supervivencia y convivencia de diferentes niveles históricos como síntoma de su inserción en el contexto urbano. En la comuna 3 y en general en las laderas de Medellín coexisten muchas formas de habitar la ciudad en un entramado biopolítico que no es lineal ni historicista en lo que podría ser llamado conteporaneidad estética.

En este sentido, el aspecto estético tiene una cierta connotación de exceso y de extrañamiento: lugares desolados y espacios devocionales en mitad de la carretera
Buenos Aires, Argentina. Doctoranda en Historia y Artes de la Universidad de Granada (España). Correo electrónico: nmvargas@udem.edu.co ORCID: bttps://orcid.org/00000002-6542-5101

*** Docente de tiempo completo e investigador de la Facultad de Ciencias Sociales y Humanas de la Universidad de Medellín. Doctor en Antropología de la Universitat Rovira $i$ Virgili de Tarragona (España), magister en Historia e historiador de la Universidad Nacional de Colombia. Correo electrónico:hcardona@udem.edu. co ORCID: https://orcid. org/0000-0002-6778-2102

\section{territarias 41}

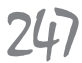


nos invocan a la reactualización de la cultura popular religiosa y nos transporta a un lugar de teatralidad popular. Podemos traer y comparar algunas coincidencias de la cultura popular chicana, la cual en los años 70 del siglo pasado comenzó como un movimiento resistente, que política y culturalmente tenía por objetivo llamar la atención hacia la mexicanidad en la frontera sur de Estados Unidos.

En la contemporaneidad, estas manifestaciones estéticas chicanas están vinculadas a la vida cotidiana. Por lo tanto, retratan momentos de hibridación o ciertos sincretismos entre sus orígenes y la vida norteamericana. Así se revelan momentos relacionados con la manera de vivir de la gente y no tanto con las luchas identitarias, lo cual se hace patente en la serie fotográfica que acompaña este artículo. Asimismo, los chicanos representan oficios de su economía informal a la cual están abocados por ser "ciudadanos de segunda": vendedores ambulantes, negocios de comidas, tacos mexicanos, tamales, elotes, etc., los cuales pueden verse representados en los altares y muros californianos.

Así como La virgen de Guadalupe es objeto de adoración chicana, tenemos en Medellín la imagen de la virgen del Carmen como objeto de devoción. Imágenes que condensan el gusto popular y las representaciones culturales de lo religioso. Muchos de estos altares a las vírgenes tanto en una geografía como en otra se atiborran de ofrendas: flores, fotografías de hijos perdidos o ausentes e imágenes del sincretismo religioso popular. Existe una semejanza en esta transposición de valores entre las prácticas devocionales chicanas y los altares campesinos: se trata de un movimiento de gestos devocionales que invierte el sentido de lo alto y de lo bajo, de lo popular y lo artístico para dar lugar a una nueva síntesis en el "gusto" o el "mal gusto" que integra nuestro imaginario estético urbano. He aquí una forma de producción artística que podríamos llamar naif y que resiste al gran arte, que puede leerse inicialmente como un naturalismo romántico o como un mero folclorismo en el que se hace una idealización de la vida rural. Sin embargo, esta mirada es posible cuestionarla con la riqueza simbólica e icónica de las fotografías que aquí se analizan: documentos antropológicos sobre los modos de apropiación urbana que han construido los habitantes de los barrios populares en Medellín.

Esta estética se basa en la experiencia de las clases bajas en las que la transformación diaria de los objetos presentados en forma de arte decorativo o en ceremonias populares, ritualidades, como es el caso del día de muertos para los chicanos y mexicanos, se convierten en una presentación estética de los modos de apropiación de lo urbano. Aquí se percibe un arte de lo sincero, intuitivo, desafiante, inventivo, irreverente y excesivo en el que la transformación del imaginario fragmentado, coexistencias de estéticas de lo cotidiano, subyace en la construcción de entornos por parte de los sectores populares (casas, exteriores, fachadas o adornos). Como constantes de estos entornos construidos 
por sectores populares encontramos la reiteración, la saturación, el mosaico, el bricolaje y los apilamientos, amontonamientos y acumulaciones que se convierten en el sentido presentado por Tartarkiewicz (2015) en una comprensión del arte como una actividad humana capaz de reproducir cosas, construir formas o expresar una experiencia si el producto de esta reproducción, construcción o expresión puede deleitar, emocionar o producir un choque (performatividad estética). Desde esta mirada se apuesta por una definición alternativa que intenta responder a la diversidad de exigencias que emergen en la contemporaneidad y a las distintas funciones y significaciones sociales del concepto de estética.

Es importante referenciar los inicios de la planeación urbana de la ciudad de Medellín porque en ella se fundan las bases de lo que se entenderá por desarrollo urbano desde comienzos de la segunda mitad del siglo Xx. En este sentido, tiene especial énfasis el desarrollo de la zonificación por función, para poder configurar esta nueva ciudad funcional se hizo necesario implementar en Medellín el concepto de la unidad vecinal planteado por el arquitecto y urbanista francés Le Corbusier y retomado por José Luis Sert y Paul L. Wiener, quienes fueron contratados por el Concejo de Medellín en 1947 para realizar un proyecto de planificación de la ciudad futura:

Abordar conceptos como ciudad, territorio y población, es poner en juego imaginarios urbanos y estéticos del habitar que hacen del espacio un entramado biopolítico difuso. Este es el caso de la ciudad de Medellín, capital del departamento de Antioquia (Colombia), entre 1945 y 1951, cuando hacia 1946 el español José Luis Sert y el austriaco Paul L. Wiener son contratados por el Concejo de Medellín para realizar un proyecto de planificación de la ciudad futura, a partir de los modelos del arquitecto francés conocido como Le Corbusier, se planteó un reordenamiento de la ciudad que llevará a ser conocido como Plan de Desarrollo Urbanístico de la Ciudad en 1951. El plan piloto de estos arquitectos propuso la construcción de un centro administrativo en el sitio denominado La Alpujara, cercano al sector de Guayaquil, ligado a la actividad comercial, con el objetivo de construir en los alrededores del centro administrativo, unidades educativas, de seguridad y cultural. Desde 1946 se planteó una ciudad fluida ligada a la circulación biopolítica del cuerpo social, la población. Sin embargo, este tejido biopolítico ligado a un imaginario de ciudad concebida, vinculada al control de la población no puede disciplinar completamente el interaccionismo simbólico que entrañan los juegos de apropiación estética y prosaica de la ciudad vivida y percibida, el cuerpo social pone en juego diversas tácticas que hace de lo urbano un conjunto de apuestas de resignificación humana del espacio construido (Cardona, 2015, p. 91).

En las fotografías aquí presentadas se han seleccionado representaciones de espacios que resultaban ser escenarios tersitarias 41 249 
${ }^{1}$ Creación, imaginación $y$ ciudad se fusionan en la expresividad humana de lo urbano deviniendo territorio como un espacio del marcaje simbólico: "el territorio está esencialmente marcado, por 'indices', $y$ estos indices son extraidos de las componentes de todos los medios: materiales, productos orgánicos, estados de membrana o de piel, fuentes de energía, condensados percepción-acción. Precisamente, hay territorio desde el momento en que las componentes de los medios dejan de ser direccionales para devenir dimensionales, cuando dejan de ser funcionales para devenir expresivas. La emergencia de materia expresivas (cualidades) es la que va a definir el territorio." (Deleuze \& Guattari, 2004, p. 321).

${ }^{2}$ Hablar de chicano, según el Diccionario de la Lengua Española (1992), hace referencia al uso de una expresión en francés (chicane) en tanto una artimaña o procedimiento de mala fe, pero también una broma o chanza. Igualmente, es una aféresis de mexicano al designar al ciudadano de los Estados Unidos de América que integra una minoria de origen mexicano, quienes ponen en escena un movimiento

\section{tersitarios 41}

íntimos de significación para las personas, que incluso podrían denominarse "pequeñas cartografías visuales" de creencias que se hicieron explícitas en las colecciones de objetos que siguen la disposición de altares, o en la captura desprevenida de escenas naturalistas la evocación de íconos religiosos cristianos conectados con la cultura campesina antioqueña. En todas es posible identificar rasgos de la historia familiar y personal o como se podría denominar según la tradición antropológica: algunas de las costumbres que permiten comprender mejor el sentido que estas personas le dan a su existencia y la carga simbólica que habita su cotidianidad.

El habitar la ciudad pone en juego la coproducción o copresencia entre los flujos sociales y los dispositivos de poder ${ }^{1}$, donde confluyen los espacios planeados y construidos. He aquí el animal público que habita lo urbano transgrediendo las estructuras haciéndose estructurante con ellas. En este sentido, reflexionar sobre la ciudad no tiene solo que ver con el orden, sino también con la evocación de la existencia del desorden dinámico ya que comprenderla requiere ir más allá de la razón instrumental de la regulación y la planeación y de lo estructurado, lo geométrico o racional para dirigirse hacia un espacio de libertad que entraña otras racionalidades y estéticas que reafirman la existencia.

Más allá de los planos y las maquetas, la urbanidad es sobre todo la sociedad que los ciudadanos producen y cómo la forma urbana es gastada, por así decirlo, por sus usuarios. Son estos quienes, en un determinado momento, pueden desentenderse - y de hecho se desentienden con cierta asiduidad-de las directrices urbanísticas oficiales para constelar sus propias formas de territorialización, modalidades siempre efímeras de pensar y utilizar los engranajes que hacen posible la ciudad (Delgado, 1999, p. 181).

\section{Costumbres y universo simbólico en las estéticas urbanas}

El concepto de costumbre que se dispone en este texto para leer la estética chicana ${ }^{2}$ en Medellín guarda una directa relación con el conjunto de valoraciones, percepciones, representaciones e imaginarios entre personas, objetos y relaciones. En este sentido sostiene Castaingts (2002):

Las costumbres. En las sociedades, los individuos generan dispositivos habituales, los cuales, cuando se generalizan y perduran durante cierto tiempo, se convierten en costumbres. Las costumbres se viven como positivas o buenas y lo que se aleja de ellas se vive como transgresiones. Las costumbres, además, suelen tener una vida de inercia bastante fuerte. Así, las costumbres son una fuente importante de valoración de personas, objetos y relaciones (Castaingts, 2002, p. 160).

Igualmente, respecto al concepto de símbolo, es valiosa la manera en que Solares (2011) interpreta el trabajo de Gilbert Durand (1971), quien ha sentado la base 
teórica sobre la que se cimientan muchos de los postulados que en el presente texto encuentran lugar (topoi reflexivo):

El símbolo nace de la capacidad del hombre de interpretar la realidad siempre de una manera distinta, enriqueciéndola y dotándola de sentido. No solo reúne a las partes, sino a las partes aisladas del mismo individuo enajenado respecto de su propio ser. El símbolo está en el límite de lo concreto y lo difuso, lo consciente y lo inconsciente, lo presente y lo que se presiente. En otros términos: se simboliza en situaciones límite, de carencia, de inacabable búsqueda, de exploración, de conjetura que - comenta Cacciari- "es la auténtica revelación de lo que de ningún modo puede ser desvelado. Es la forma en la que conocemos la inefabilidad de lo indefinible" (...) El símbolo es el medio a través del cual el sentido puede manifestarse y realizarse [puesto que] el símbolo alude a una metafísica o bien, como también lo anotan algunos filósofos, toda metafísica es simbólica. El símbolo alude a una realidad abierta difícil de presentar y que por lo tanto solo puede ser referida de forma simbólica (...) [De hecho] las expresiones de lo simbólico pueden clasificarse en tres actos: los gestos, que dan lugar al ritual, música y danza; la creación plástica de la que se deriva el arte visual, y las palabras, de las que nacen el mito, la poesía y la literatura (Solares, 2011, pp. 15, 17, 18 y 19).

Los acontecimientos de los rituales campesinos descritos en este texto mediante las fotografías propiciadas por los participantes del proceso evocan prácticas espirituales ${ }^{3}$ comunitarias o individuales; retratan sus costumbres, a la vez que traen a la memoria el espacio de lo sagrado, lo silencioso, lo misterioso y lo lento, y simbolizan la cotidianidad por medio de representaciones plásticas de sus interpretaciones del mundo. Partiendo precisamente de que el símbolo está en el límite de lo concreto y lo difuso, lo consciente y lo inconsciente, lo presente y lo que se presiente; tal cual lo reitera Solares (2011), los espacios presentados en las fotografías hacen evidentes procesos interculturales que permanentemente cruzan las fronteras del pasado y el presente, de lo sagrado y lo profano abriendo un espacio para el reconocimiento de la singularidad estética campesina que todavía habita la ciudad de Medellín y que ha mutado para relacionar objetos heteróclitos en lo que podemos reconocer como ritualidades contemporáneas. Las costumbres en este texto son escenarios íntimos de significación, pequeñas cartografías de creencias que se hacen explícitas en las colecciones de objetos que siguen la disposición de altares o en la captura desprevenida de escenas naturalistas que evocan íconos religiosos cristianos muy conectados con la cultura campesina antioqueña.

Para Clifford Geertz (2003), cultura es la manera en que los seres humanos explican el mundo y lo que les rodea, y a la vez, a otros, lo que le otorga sentido a las experiencias vitales: "Un esquema históricamente transmitido de significaciones representadas en símbolos. Un sistema reivindicador del libre desarrollo de la cultura y del goce total de sus derechos civiles y políticos.

${ }^{3}$ Según Wassily Kandinsky, en sus reflexiones sobre lo espiritual en el arte (1989), este último es hijo de su tiempo, refleja una época espiritual de vértigos $y$ tensiones en una atmosfera visionaria y misteriosa. Asi, "no solo es eco y reflejo de ella, sino que contiene energía profética vivificadora que actúa amplia $y$ profundamente. La vida espiritual, en la que también se halla el arte y de la que el arte es uno de sus más fuertes agentes [así como las formas simbólicas de lo cotidiano] es un movimiento complejo pero determinado, traducible a términos simples, que conduce hacia adelante y hacia arriba. Este movimiento es el conocimiento. Puede adoptar muchas formas, pero en el fondo mantiene siempre un sentido interior idéntico, el mismo fin" (p. 13).

\section{territarias 41}

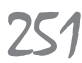


de concepciones heredadas y expresadas en formas simbólicas por medios con los cuales los hombres comunican, perpetúan y desarrollan su conocimiento y actitudes ante la vida” (p. 88). Sin la cultura así entendida "las personas serían criaturas inviables, debido a que dependen enteramente de los símbolos y de sistemas de símbolos para comunicarse, crear y sobrevivir" (Geertz, 2003, p. 86).

Como práctica estética y como práctica cultural esta recurrencia a los altarcitos caseros y a la memoria de las iconografías religiosas en espacios públicos se puede leer como una permanencia en la memoria colectiva de la necesidad del ritual como parte de la vida cotidiana. Las expresiones lingüísticas y religiosas del hombre no son un simple medio de comunicación económica de mensajes. Los mitos y sus expresiones, los vestigios a partir de los cuales es posible reconstruir el sentido de su cultura tienen una expresión simbólica que no se agota en sistemas de signos para la mera legitimación de poderes fácticos; por lo demás, sucede que esta visión estrecha deriva del mal uso de una noción de "ideología" que es un término específico de la modernidad ilustrada. El pensamiento religioso del hombre no es prerracional o precientífico ni su lógica está desarticulada, por el contrario, responde a una lógica restrictiva derivada de modelos de reglas semánticas y sintácticas de los hechos del lenguaje reforzadas por componentes neurobiológicos y afectivos que el análisis hermenéutico o "mitoanálisis" debe descubrir como lo recuerda
Solares (2011) al evocar los estudios de Gilbert Durand.

\section{Medellín como espacio rururbano}

Medellín es una ciudad colombiana relativamente joven que se originó con el poblamiento del valle de Aburrá y se perfiló como una de las más importantes del país. Su zona central es relativamente de fácil acceso, está asentada sobre la parte más aplanada del valle que fue poblada sobre todo hacia la primera mitad del siglo XX por el interés de sus gobernantes y fundadores de convertir una antigua villa rodeada de caseríos en una verdadera ciudad que además se ha querido proyectar como capital industrial, económica y política no solo de Antioquia sino a nivel nacional. Sin embargo, sus ambiciones superan por mucho el espacio que tiene para expandirse ya que la geografía misma del valle donde se aloja implica una proyección del suelo singular: una pequeña zona plana rodeada de montañas escarpadas.

De ahí que su invitación a ser poblada tiene una advertencia inicial de falta de espacio para personas que no puedan pagar el valor del suelo en su centralidad y esto ha implicado que como ciudad se reconfigure constantemente puesto que quienes más acuden a su llamado son los campesinos que llegan buscando un futuro económico más próspero, pero quienes se encuentran con una ciudad inasequible para sus posibilidades reales de existencia.

Medellín, constituida en un espacio que abarca lo rural y lo urbano, en cuyo 
interior se combinan lo central y lo periférico, no es por lo tanto un ente inmóvil e inanimado, sino que adquiere una serie de significados conforme a las estéticas que en ella coexisten y se transforma a medida que las formas culturales son experimentadas y puestas en escena en fenómenos urbanos de apropiación. Unido a ello, en tanto territorio en multiplicidad temporal, articula lugares de memoria social en los cuales es fácil comprender la relación que sus habitantes establecen entre ellos mismos, pero también con aquellos componentes físicos (construcciones o paisajes arquitectónicos).

La distribución desigual del espacio ocurre tanto de manera cuantitativa como cualitativa. Los terrenos que están mejor ubicados, físicamente mejor dotados o más valorizados por la inversión de capital son ocupados por rentistas y por las clases económicamente pudientes. Los espacios más alejados de los mercados, de los sitios de consumo, físicamente inadecuados, mal dotados y desvalorizados desde la renta del suelo son los lugares de residencia de los menos favorecidos de la ciudad. De esta forma, también a nivel del espacio habitado, se expresa la discriminación, la diferenciación social y las relaciones sociales. Del mismo modo, la segregación espacial se manifiesta en la existencia de un gran número de propietarios de espacios muy pequeños, mientras que en otros sectores de la ciudad existen muy pocos propietarios con grandes extensiones territoriales.
Los sectores populares acceden a tierras improductivas y no urbanizables; la posibilidad que tengan estas de incorporarse al mercado urbano y valorizarse está dada por las transformaciones que introduce el trabajo comunitario y la inversión estatal, no solo se valorizan estos terrenos, sino los cercanos; de ahí que en estos sectores la dotación, legitimación, ordenamiento y remodelación sean asumidos por el Estado que debe intervenir, normalizar, estandarizar y adecuar. Para integrar estos espacios públicos a la función urbana se han creado una serie de entidades: OOPP y EPM para espacios públicos y equipamiento de uso colectivo; ICT, Corvide y Primed para mejoramiento de vivienda, y otras entidades para salud y educación.

Este crecimiento desenfrenado de la ciudad obligó a que en 1993 se integraran las periferias urbanizadas al perímetro urbano ampliado, lo cual ha significado que los barrios emergentes consolidaran sus territorios y mejoraran sus infraestructuras y sus equipamientos urbanos dosificando con ello su ocupación territorial sin disminuir las problemáticas antes mencionadas al multiplicarse la población y aumentar el perímetro urbano en las laderas de la ciudad.

Por lo anterior, gran parte de estas zonas que persisten en el límite de lo urbano y lo rural, entre lo aceptado por la ciudad como parte de su suelo y lo que su administración rechaza y considera "montaña”, ponen en juego el límite fronterizo entre Medellín y sus periferias. territarias 41

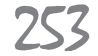


El fenómeno de poblamiento de las laderas continúa con familias que luchan por tener un lugar para habitar a pesar de las condiciones socioespaciales, lo cual permite comprender que si bien dicha frontera es estática en los mapas y representaciones cartográficas oficiales, en la realidad lo que se vive es muy distinto: oleadas de habitantes que arriban a la ciudad aspirando a tener un lugar para habitarla. Un proceso de poblamiento en el que estas personas terminan por transformar sus hábitos rurales de origen con el fin de adaptarse a las condiciones culturales de los barrios que construyen con su llegada y que por contexto imponen una lógica urbana tanto en sus cotidianidades como en sus representaciones simbólicas. He aquí el vínculo que se proyecta en este texto entre estéticas chicanas y fenómenos de poblamiento periférico en Medellín, caracterizados por dinámicas urbanas de apropiación, resistencia y adaptabilidades de las comunidades que habitan, viven, perciben, transitan y moran los espacios urbanos.

De un lado, son el producto de un diseño urbanístico y arquitectónico políticamente determinado, cuya voluntad es orientar la percepción, ofrecer sentidos prácticos, distribuir valores simbólicos e influir sobre las estructuras relacionales de los usuarios. Del otro, en cambio, es el discurso deliberadamente incoherente y contradictorio de la sociedad misma, que es siempre la que tiene la última palabra acerca de cómo y en qué sentido moverse físicamente en la trama propuesta por los diseñadores. Es el peatón ordinario quien reinventa los espacios planeados, los somete a sus ardides, los emplea a su antojo, imponiéndole sus recorridos a cualquier modelamiento previo políticamente determinado. En pocas palabras, a la ciudad planificada se le opone -mediante la indiferencia y/o la hostilidad - una ciudad practicada (Delgado, 1999, p. 182).

\section{El barrio Bello Oriente: un territorio de invasión}

Los desarrollos en la zona nororiental de Medellín, al igual que muchas otras laderas de la ciudad, no son homogéneos. Debido a las múltiples oleadas de pobladores, su interior se compone de barrios antiguos, barrios piratas, barrios de invasión y una cuarta modalidad generada por casitas entregadas por instituciones de beneficencia que pretenden organizar el suelo y distribuir techos a la población. De hecho, gran parte de su conformación se dio mediante el proceso de loteo, venta y fraccionamiento de terrenos que se convierten en hogares mediante la autoconstrucción y originan los famosos barrios piratas o de invasión, conformados por migrantes pobres provenientes del campo que llegan por razones que van desde las personales hasta las económicas, sociales y políticas.

Poco a poco surgen nuevos asentamientos en áreas de riesgo, especialmente a lo largo de las quebradas La Rosa y La Careciera, en la parte alta de los barrios Carpintero, María Cano y Carambolas y los asentamientos de los barrios Aldea, Pablo 
VI y el Compromiso (sector La Torre). En la década de los años 80, se invaden las cañadas de Villa del Socorro, Andalucía, San Blas, El Jardín y Las Nieves, fuera del perímetro urbano, y se establecen los asentamientos de María Cano, Carambolas, San José, La Cima 1 y 2, Versalles, La Cruz parte alta y baja, La Avanzada, La Esperanza, El Compromiso, Carpinelo, Bello Oriente y El Trébol.

Los invasores iniciales se convirtieron en urbanizadores piratas que fragmentaron los predios impulsando el desarrollo de sectores intermedios más internos y aislados que hicieron necesaria la conformación de nuevos senderos secundarios. Sectores críticos como los escarpes de montaña superan la cota de servicios y los cauces de las quebradas y sus retiros reciben una fuerte presión por los nuevos invasores, que da como resultado sectores como La Cruz y El Chispero en el barrio Carpinelo. Las calles que se trazaron inicialmente como senderos de acceso se convirtieron en vías principales pavimentadas y las de mayor pendiente pasaron a ser escalas o rampas. Las viviendas fueron conformando incipientes manzanas de trazado irregular, orientado hacia las vías principales.

El barrio Bello Oriente, predominantemente pobre, es precisamente uno de los muchos de la zona nororiental que corresponde con los últimos asentamientos poblacionales. Construido en las laderas del valle de Aburrá por personas que llegaron a esta ciudad después del segundo tercio del siglo XX, quienes estaban imposibilitadas para habitar el centro urbano ya sobrepoblado y costoso, tuvieron que ubicarse en las laderas de la ciudad luchando contra la gravedad aferrándose a las montañas. Este es justamente uno de los puntos clave para entender las ideas que se resaltan en el presente escrito.

De esta forma, se puede decir que el poblamiento de las zonas de periferia y laderas en Medellín se ha caracterizado, a través de la historia, por ser una ocupación diferencial en el tiempo y en el espacio, que se ha realizado por la confrontación, asimilación y ruptura de valores y prácticas culturales tradicionales. Los nuevos habitantes han tenido que integrarse a la cultura urbana formal, desvirtuando la cultura local propia y trasladando sus prácticas y formas campesinas al territorio urbano. Este comportamiento propicia un híbrido cultural que combina elementos de lo rural y lo urbano que se materializan en el asentamiento.

\section{Elementos de la estética chicana en Bello Oriente}

La población del barrio Bello Oriente en la ciudad Medellin, tiene una historia, una idiosincrasia y un sistema de símbolos entendidos como "formulaciones tangibles de ideas, abstracciones de la experiencia fijadas en formas perceptibles, representaciones concretas de ideas, de actitudes, de juicios, de anhelos o de creencias" (Geertz, 2003 , p. 90)— que le son propios y que, aunque cambiantes a través del tiempo, se ha mantenido y exaltado a algunos de ellos como estandartes de su identidad territarios 41

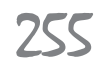


${ }^{4}$ En este artículo además de seguir los postulados de Gilbert Durand (1971), se dispone en función reflexiva la concepción de Carl $G$. Jung de las "imágenes primordiales" o estructuras arquetípicas definidas como representaciones simbólicas en los modos de ver que modelan aquellas prácticas espirituales comunitarias $o$ individuales que fueron mencionadas antes. Según Jung (1976), "las imágenes primordiales son los pensamientos más antiguos, generales y profundos de la humanidad. Tienen tanto de sentimientos como de pensamientos; es más, poseen algo así como una vida propia e independiente, como aquella especie de alma parcial, que podemos ver fácilmente en todos los sistemas filosóficos o gnósticos, que se basan en la percepción de lo inconsciente como manantial del conocimiento (p. 84).

5 Sobre el concepto de cultura hibrida en el contexto urbano pueden consultarse Grau-Solés, ÍnaguezRueda y Subirats (2012) y Palmett Plata (2015). Esta última sostiene que "la desigualdad de recursos, de oportunidades y de calidad de vida entre miembros de una misma población es un fenómeno que caracteriza a

\section{territarias 41}

y parte fundamental de su imaginario. Solares (2011), explicando la concepción de cultura de Gilbert Durand, establece que el imaginario constituye el "sustrato básico de la vida mental, que, lejos de agotarse en la producción de conceptos o en la mera praxis instrumental, alude a una dimensión del anthropos a partir de la cual el hombre elabora su interpretación del mundo" (p. 14).

En el contexto veloz de las sociedades contemporáneas, además de líquido y vaporoso siguiendo a Zygmunt Bauman (1999), donde cada vez hay menos tiempo para el ritual, la cultura se constituye en una práctica de resistencia y por lo tanto en un aspecto necesario para desarrollar procesos de sostenibilidad en estas $\mathrm{co}^{-}$ munidades. En este apartado se busca presentar una conexión entre estos altares encontrados por los participantes del proceso de sensibilidad visual participante en el barrio Bello Oriente y el arte chicano.

No se trata de una relación de parentesco, es decir, no deviene uno del otro, sino que se identifica una estructura arquetípica del comportamiento simbólico ${ }^{4}$ de ciertas culturas híbridas ${ }^{5}$ que dan material de reflexión en el campo de las ciencias sociales y humanas.

La estética chicana comienza con los llamados "pachucos" asentados en Los Ángeles (EE.UU.) después de la postguerra, personajes desarraigados que buscan su identidad como lo cuenta Octavio Paz (1985) en El laberinto de la soledad:
Al iniciar mi vida en los Estados Unidos residí algún tiempo en Los Ángeles, ciudad habitada por más de un millón de personas de origen mexicano. A primera vista sorprende al viajero —además de la pureza del cielo y de la fealdad de las dispersas y ostentosas construcciones- la atmósfera vagamente mexicana de la ciudad, imposible de apresar con palabras o conceptos. Esta mexicanidad - gusto por los adornos, descuido, negligencia, pasión y reserva - flota en el aire. Y digo que flota porque no se mezcla ni se funde con el otro mundo, el mundo (p. 12).

Se trata de una sociedad en la que la cotidianidad es una práctica sincrética que se realiza a partir de la mezcla de creencias religiosas y costumbres para lo cual elaboran altares como una práctica tradicional dentro de los espacios representacionales, cargados de complejos simbolismos, generalmente relacionados con objetos, creencias e imágenes de diversa procedencia. De esta sociedad se deriva el arte chicano, que se reconoce como un proceso de resistencia creativa y de expresión artística de quienes optaron por quedarse en las tierras al norte de la frontera entre Estados Unidos y México.

El arte chicano se manifiesta a través de la literatura, la pintura, los murales, la música y el cine. Estas manifestaciones culturales de los chicanos se caracterizan por la utilización de símbolos religiosos, políticos e indígenas y el reflejo de sus problemas sociales y de identidad. El arte 
chicano es también considerado como un arte temperamental que refleja el alma de su gente, su sentir, su vivir y su esperanza (Soto, 2003, p. 40). Se trata de un arte comparativo que analiza el perfil sociológico y refleja la vida diaria del chicano, planteando sus problemas de identidad. Sus manifestaciones artísticas se resumen como protesta al unir elementos propios y reencontrar sus raíces sin aceptar modelos externos (Kartofel, 1985, p. 16).

\section{Altares cotidianos en la comuna 3 de Medellín}

En el caso del presente análisis esta experiencia artística e histórica específica del arte chicano ayuda a contextualizar el trabajo logrado con las fotografías. En primer lugar, una de las razones para encontrar esta conexión es el trabajo de resistencia y transformación de fronteras implícitas y explícitas referidas al territorio, pero también a las creencias que se proponen en el arte chicano y que sirven de categorías de análisis para las fotografías logradas. Si bien no es posible hablar de fronteras entre dos países distintos, sí es posible hablar de fronteras construidas entre pueblos distintos y una ciudad, descritas ampliamente en este artículo y de las cuales reconoceremos otra característica en este apartado.

En segundo lugar, como se podrá ver en el análisis específico de las imágenes, en el arte chicano al igual que en las fotografías, el manejo espacial de los objetos de la vida cotidiana mezclados con icono- grafía religiosa se complementa creando escenografías efímeras que dan cuenta del modo como la ritualidad y la religiosidad han encontrado las fisuras por las cuales crecer en las ciudades contemporáneas. El arte chicano ha tenido múltiples representantes y una conexión muy fuerte con el muralismo mexicano en sus comienzos. Sin embargo, para el presente análisis es más pertinente la referencia a las artistas que han optado por las instalaciones que hacen un reconocimiento de las estéticas del "altarcito" mexicano; en este caso se presenta a continuación la obra de Dana Salvo. Para efectos del contraste y comparación entre los diversos elementos del arte chicano y las fotografías presentaremos inicialmente aquellas de los participantes y luego la de la artista mencionada.

En la figura 1 se toma un plano general de una casita acomodada por los habitantes del barrio Bello Oriente con la lógica de un lugar de oración. Aunque está cruzada por las barras de madera que hacen las veces de columnas, pueden verse en el fondo dos altares. Uno en el que la figura central es el niño Jesús; los telones del escenario sagrado están constituidos por sábanas y cortinas que los mismos habitantes donaron para adornar el sitio; como es característico de estas ritualidades al lado derecho de la figura se encuentra escrita una frase de alabanza a esta figura divina. No obstante, lo más interesante es que por el tipo de caligrafía podemos notar que fue hecho con materiales que los habitantes tenían a mano, probablemente con temperas recicladas o encontradas.
$\Longleftarrow$

la mayoría de las sociedades contemporáneas y su intensidad es tal, que empapa las formas de vestir, los estilos de vida y los espacios físicos. El contraste entre fragmentos urbanos, verdes y de concreto, riqueza y pobreza se hacen visibles en la ciudad híbrida, siendo única, inigualables y particular, pero no por eso la mejor vista de la ciudad. Medellín indis cutiblemente es una ciudad de contrastes, en donde la hibridación se hace presente permanentemente con la forma de habitar los espacios y de mostrar sus avances arquitectónicos y tecnológicos" (Palmett, 2015, p. 114).

territorias 41

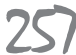


Figura 1. Interior: lugar de oración. Barrio Bello Oriente, Medellín

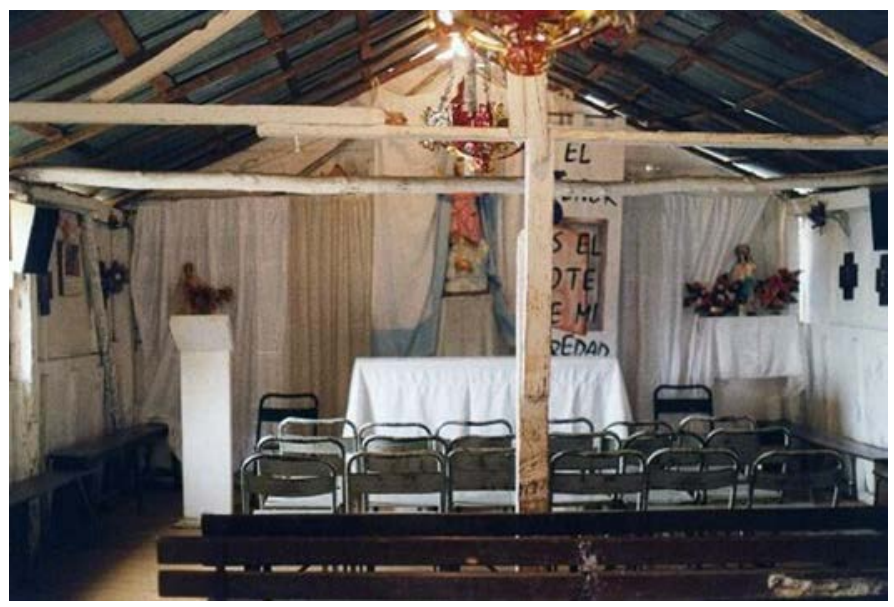

Fuente: fotografía Grupo de Trabajo Bello Oriente, dirigido por Nora Margarita Vargas (2012).

tersitarias 41 258 do, vale aclarar que si bien estas personas son católicas en su mayoría y que esta religión centra sus creencias en Dios y en la trinidad como representación de este, la virgen como figura femenina tiene mucho peso para las personas creyentes que los igualan simbólicamente (casi como una par en cuanto a su alcance mágicoreligioso). Evidentemente en el altarcito esta relación de poderes es visible y permite generar reflexiones en torno a la figura de lo femenino en la cultura paisa.

La zona andina colombiana tiene una herencia cultural indígena predominantemente muisca, en la que la mujer como madre del universo tiene una connotación mágico-religiosa similar a la de la virgen, como la entienden los antioqueños. Algunas reflexiones coinciden en que la matrona es una figura que mezcla el poder de la diosa Luna o Bachué (la fecundidad) con el de la virgen María. La Madre Bachué, madre primigenia del pueblo muisca que alimentó con sus pechos a esta comunidad representa a la mujer madre y creadora, lo cual se expresa en la imagen de María en el imaginario de las mujeres de Antioquia, quienes le ruegan por favores y bendiciones con el mismo e incluso más fervor con el cual se dirigen a la imagen de Dios padre. Una relación persistente que unifica en un solo altar las creencias de un pasado indígena supuestamente perdido con las creencias de un presente católico en un universo simbólico que ordena la realidad en un sincretismo constituyente y de hibridación cultural.

Como puede verse, el espacio retoma elementos encontrados, nuevamente 
a modo de bricolaje ${ }^{6}$ : sillas de distintos materiales se han ubicado en ese lugar con la intención de convertirlo en un territorio de reunión de la comunidad en torno seguramente al ritual religioso de la misa. Sin embargo, la mirada del fotógrafo es interesante pues decide mostrarnos el espacio vacío y esto permite ver su constitución espacial y objetual de un modo más explícito. Un aspecto final que es posible mencionar respecto de esta fotografía es la importancia que este tipo de escenarios supone para la comunidad ya que por estar alejados del centro de la ciudad y por ser barrios construidos por fuera de la planeación urbana "oficial", generalmente no cuentan con escenarios para el encuentro colectivo o la expresión de sus rituales. Este espacio es muy significativo porque toda la comunidad aportó elementos que lo convierten en un collage de objetos importantes que cada habitante pone allí, no es una habitación prefabricada ni funcional ni minimalista en la que prime la necesidad de agrupar muchos cuerpos en un espacio con condiciones de higiene y seguridad; es un escenario hecho de retazos, de historias personales y de memorias, un escenario que en cada objeto tiene el peso de la vida de quienes van a orar en él.

En las figuras 2 y 3 se visualizan dos altares de la virgen María sosteniendo al niño Jesús. Entre los campesinos que han poblado la ciudad de Medellín en los procesos de migración, desplazamiento y explosión demográfica que acontecieron dramáticamente entre los años 70 y 90 del siglo $\mathrm{Xx}, \mathrm{y}$ que aún acontecen en menor escala, esta figura religiosa es muy importante no solo en el barrio Bello Oriente, sino en las otros barrios ubicados en las comunas, donde es característico encontrar estos altares a la virgen María en las calles, los parques y demás espacios públicos.

En estos altares, desde el punto de vista formal, es importante reconocer cómo se construye con cuidado una pequeña casa en la que el ícono se encuentra resguardado de la lluvia y el sol y del posible robo. Cada uno de los altares es construido con materiales que están a la mano del campesino como piedras del camino y tubos de hierro que seguramente sobran de alguna construcción; se nota el cuidado y dedicación que han puesto los habitantes del barrio en mantener el ícono en buen estado para la adoración de los paseantes. Particularmente en la fotografía 2 llama la atención que los materiales del altar de la virgen están hechos para durar en el tiempo, mientras que la casa donde habita el mismo campesino a duras penas tiene un plástico para tapar una de sus paredes laterales. Se puede observar también que María está en un pedestal y de modo lateral a la casa como una imagen de poder y protección.

En el sentido connotativo, interesa mencionar aquí que el fervor que se le manifiesta a este ícono específico de la virgen María está profundamente vinculado con su carácter de madre. Es necesario poner atención en esto, el ícono que se adora no es la piedad o la muerte de la virgen, es la madre que sostiene al hijo en brazos, la mujer campesina y pobre que representa
${ }^{6}$ En este texto se recurre al concepto de bricolaje desde la perspectiva de una antropologia estructural de Claude Levi-Strauss (1997). Esta categoría se entiende desde dos perspectivas: una concerniente al movimiento del acontecimiento como el revote de la pelota, como el perro que divaga o el caballo que se aparta del camino para evitar un obstáculo. En la serie de fotografías que se exponen se aprecia cómo este acontecimiento se presenta desde el cambio y lo efimero. Una segunda acepción de esta categoría se relaciona con el mundo del arte, donde se reflexiona el trabajo como una acción con los materiales disponibles $y$ encontrados o como un ready made (un estremecimiento de la percepción, la posibilidad de mirar las cosas de otro modo, de pensarlas, de cambiarlas, de dejarse llevar por ellas en su potencia estética, que deriva su aparente pasividad, como nos lo recuerda el artista francés Marcel Duchamp con su orinal).

\section{territarias 41}

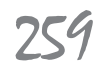


Figura 2. Exterior: altar. Barrió Bello Oriente, Medellín

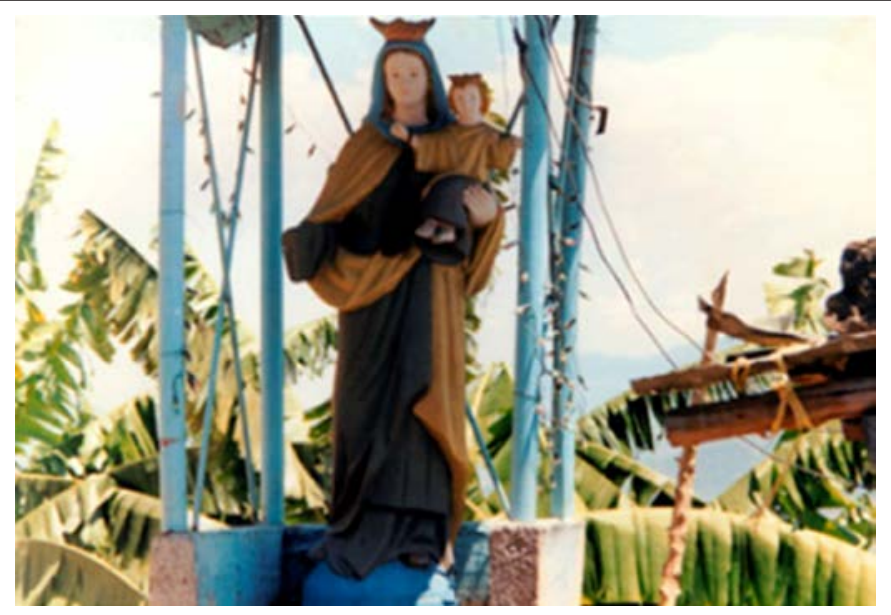

Fuente: fotografía Grupo de Trabajo Bello Oriente, dirigido por Nora Margarita Vargas (2012).

Figura 3. Exterior: altar. Barrió Bello Oriente, Medellín

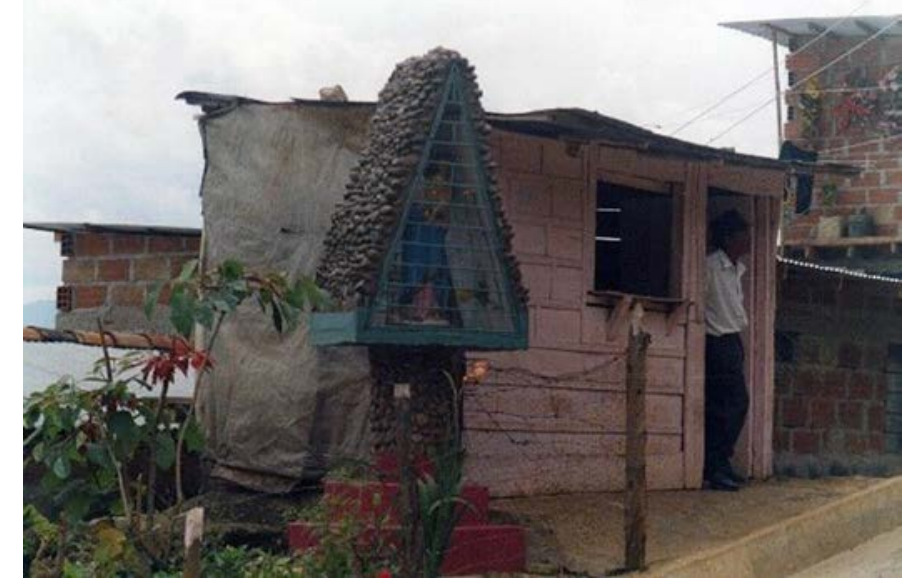

Fuente: fotografía Grupo de Trabajo Bello Oriente, dirigido por Nora Margarita Vargas (2012).

territarias 41 260
María, la encargada de cuidar a los hijos y mantener cierta armonía en el hogar, símbolo de la fertilidad y de nacimiento que evoca de nuevo a Bachué.
Para las comunidades antioqueñas la figura materna es sumamente importante en las relaciones familiares y comunitarias. La madre es una fuerte figura en el sentido más clásico como la ama de casa que se ocupa de lo doméstico y está encargada de administrar los asuntos del hogar, específicamente los relativos al alimento y a la higiene.

La mujer campesina antioqueña es precisamente una amalgama histórica de la indígena y la sirviente, la mestiza hija de criollos, africanos e indígenas o bien, la indígena "pura" que es sacada de su bohío para servir a los amos blancos. Heredera de las costumbres de los unos y los otros simboliza el paso entre lo rural y lo urbano en la época actual.

En muchos de los hogares pobres que se construyen en estos barrios llamados despectivamente "comunas", la vinculación entre este ícono religioso y el rol femenino que cumple la madre en el hogar, elevándola casi a un lugar sagrado, lleva en muchos casos a poner en manos de los hombres jóvenes de las casas el peso cultural de ser proveedores de "la cucha", apelativo que se le dice de cariño a la madre para identificarla como una persona mayor que requiere cuidado, utilizado por los sicarios - asesinos a sueldo que emergen como fenómeno de la violencia del narcotráfico en las dos últimas décadas del siglo Xx.

El ícono que aparece en los altares expresa la necesidad de la ritualidad colectiva de identificar lo sagrado en los espacios

públicos y exaltar la función vital de la 
feminidad vinculada a la maternidad; este es un sentido vitalista y positivo de estas expresiones pero al mismo tiempo representa un rasgo cultural muy complejo de la cultura campesina antioqueña, que al ser apropiado por las nuevas generaciones de algunos jóvenes que crecen en los nuevos "barrios", excluidos de posibilidades reales de empleo, educación, seguridad social y demás beneficios de la ciudad oficial optan por los caminos de la droga y la violencia para asegurar su supervivencia.

Muchos jóvenes al verse enfrentados al shock cultural que plantea comenzar a sobrevivir en la gran ciudad sin las posibilidades de educarse para ampliar sus referentes y estigmatizados por la administración municipal ven en el narcotráfico la posibilidad de encontrar dinero fácil para como ellos dicen: "mantener a la cucha a lo bien". Son convertidos por esas estructuras criminales en cuerpos dóciles en un contexto de ejércitos personales liderados por capos de la droga. Estos nuevos cuerpos dóciles adoptarán las ritualidades y los íconos como la virgen, el rosario y otras imágenes características del cristianismo para santificar incluso sus acciones más deplorables.

Es difícil reconocer la duplicidad, el claro-oscuro, que se vive en esta reinterpretación cultural del ícono de la virgen María. Sin embargo, hay que darle su peso a este rasgo en el que dichas creencias han funcionado, en ciertos momentos históricos de la ciudad, como gasolina que alimenta la chispa de la violencia, ya encendida por procesos sociopolíticos y

Figura 4. Exterior: dintel de la puerta. Barrió Bello Oriente, Medellín

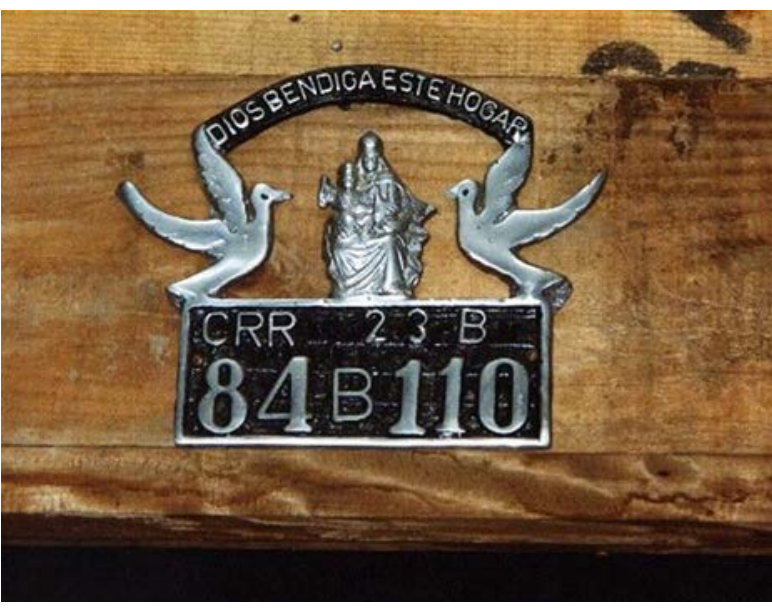

Fuente: fotografía Grupo de Trabajo Bello Oriente, dirigido por Nora Margarita Vargas (2012).

socioeconómicos de más amplia envergadura. En este sentido, y paradójicamente, la virgen representada en los altares se encuentra de un modo trágico con las figuras de las madres o matronas antioqueñas, quienes adoran a sus hijos recién nacidos, pero sospechan tristemente que tendrán que enterrarlos porque tienen una especie de destino inscrito en la que tendrán una muerte trágica.

Desde esta compleja perspectiva, es necesario expresar que si bien las ritualidades y las nuevas apropiaciones de los íconos religiosos en muchos casos sirven como escenarios de reunión, construcción, protección, conservación de la memoria y creación colectiva, en otros pueden funcionar como legitimadoras de estructuras tradicionales, que tomadas de modo acrítico y en ciertos contextos de exclusión, territarias 41 
Figura 5. Arte chicano. Artista: Dana Salvo

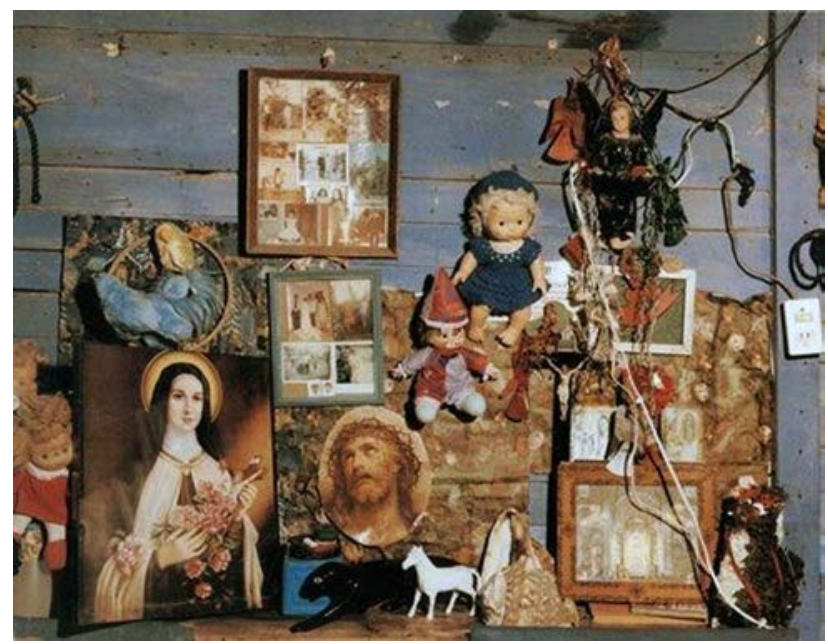

Fuente: https://www.pinterest.co.uk/pin/269160515204586935/

territarias 41 262 pueden ser legitimadoras de roles sociales vinculados a la violencia.

Aunque este texto hace referencia a los complejos procesos sociales a los que puede estar vinculada este tipo de iconografía religiosa en Medellín, interesa igualmente explorar el carácter de recreación cultural y de la memoria que construyen este tipo de manifestaciones. Si bien fueron apropiadas en ciertos casos como iconografía de la violencia, también existen otros en los que sirvieron a las comunidades y la fuerza colectiva que los mantiene unidos y les permite luchar por construir un lugar digno desde donde habitar esas ciudades oficiales que inicialmente los excluían.

Por esta razón, entra como ejemplo del arte chicano el trabajo de la artista Dana Salvo. En la figura 5 se aprecian los llamados "altarcitos" mexicanos, que son ubicados en el corazón de muchas casas mexicanas en las que se crea un foco intrincado y una espiritualidad con un profundo significado personal y familiar que refleja la vitalidad de las prácticas espirituales del país centroamericano. Algunos de estos altares son construidos para festividades especiales como días de los muertos o navidad, otros son de carácter conmemorativo para recordar a miembros de la familia, recuerdos personales significativos y memorias recurriendo a objetos que no necesariamente tienen una carga religiosa ni son directamente íconos cristianos.

En el caso de estos altares donde ya no es tan representativa la iconografía religiosa, interesa mucho el uso de objetos de la vida cotidiana y la cultura de masas para reconstruir la historia personal o familiar desde otra ritualidad no necesariamente ligada a lo religioso. En este tipo de altares, se realiza un vínculo muy interesante entre las tradiciones históricas, culturales y religiosas y las costumbres contemporáneas. Son otro modo de actualizar la ritualidad, de reinterpretarla para crear espacios personales significativos donde recurrir en este interminable ruido y velocidad que son característicos de las sociedades contemporáneas.

La figura 6 da cuenta específicamente de este tipo de altares que se hacen explícitos en el arte chicano, pero esta vez en el contexto del barrio Bello Oriente de la ciudad de Medellín. En ella se presenta un plano general en el que el marco de la puerta delimita el espacio de lo visible. Una composición que permite apreciar en 
Figura 6. Exterior: altar. Barrio Bello Oriente, Medellín

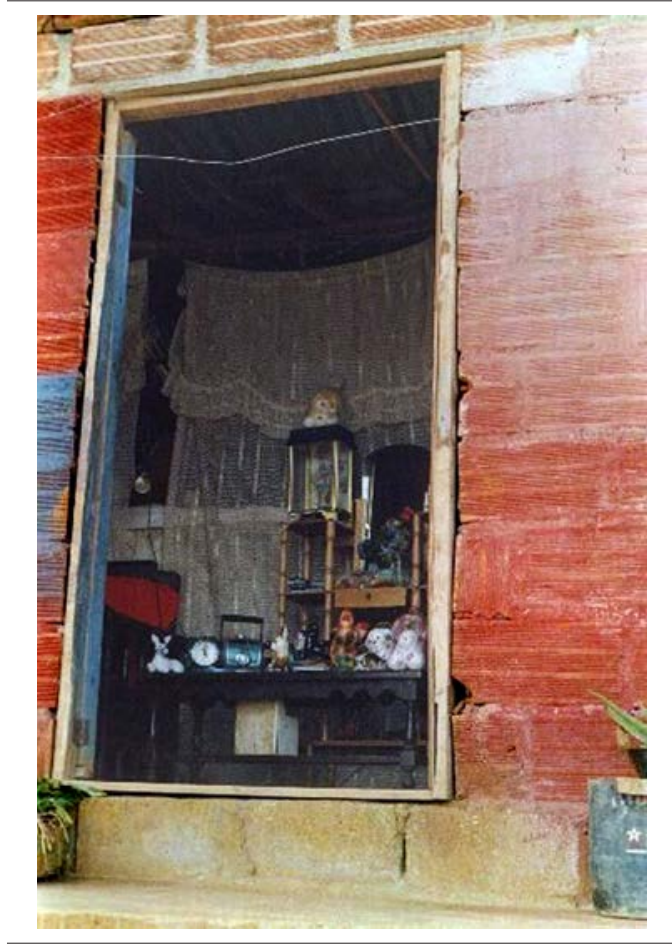

Fuente: fotografía de Nora Margarita Vargas (2012).

el interior de la casa una escena muy interesante de su vida cotidiana, que además se considera significativa. En el interior están dispuestos de un modo sistemático una serie de objetos que van narrando la historia de vida de quienes habitan la casa fotografiada. Se ve una colección de objetos como peluches, relojes, flores de plástico dispuestas frente a un espejo e imágenes un tanto borrosas que parecen ser fotografías familiares. La distribución de los objetos es recargada y produce una especie de altar barroco, en el que aparece
Figura 7. Interior: rinconcito de una casa. Barrio Bello Oriente, Medellín

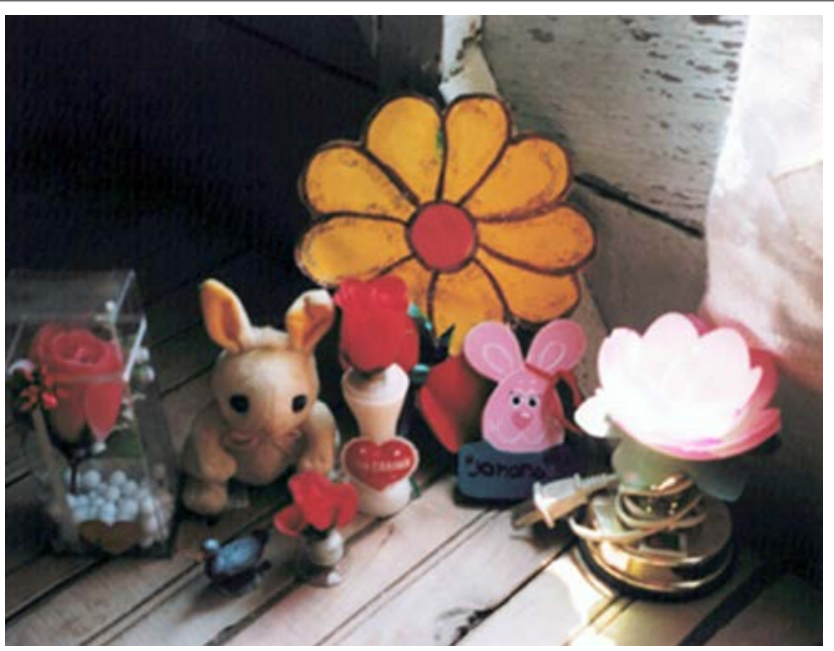

Fuente: Fotografía de Nora Margarita Vargas (2012).

la saturación y la diversidad de materiales como madera, plástico, cerámica y peluche. Detrás, y a modo de telón del altar, hay una cortina.

La figura 7 resulta inquietante y significativa porque muestra aspectos muy representativos de la estética rururbana. En primer lugar, salta a la vista el proceso de reciclaje de innumerables detalles, cada objeto fue cuidadosamente atesorado y ahora se presenta con un aura mistica. Objetos encontrados o regalados que han ido coleccionando uno o más habitantes de la casa y están ahí, a la vista, justo en la entrada de la casa para que puedan ser apreciados por los paseantes. Son el escenario de recepción y presentación y en su explicita disposición anuncian un aquí

territorias 41 
estamos quienes vivimos en este espacio en su singularidad.

Es importante identificar cómo la gran mayoría de estos objetos son considerados basura en el contexto hipertecnológico que impera en la "ciudad oficial". Mas en este espacio adquieren un valor de rastro, de signo, de memoria y de huella; dan cuenta de los espacios íntimos de una vida y una subjetividad referidos al amor, a la belleza, al entretenimiento y a la soledad.

Siguiendo en esta línea, se puede ver que la fotografía de este interior actúa como un zoom. Si bien es posible apreciar aquí también el aspecto del reciclaje y la colección de objetos significativos dispuestos a modo de espacio ritual, se hace evidente aquí una diferencia con relación a la fotografía anterior. Este pequeño rincón es un espacio privado, casi secreto. La selección de objetos es especialmente femenina y juvenil, se puede leer en el conejo el nombre de Johana. Hay en la escena un ambiente cándido de amor adolecente; el modo como la luz de la tarde ilumina los objetos que aparecen con sus distintas formas como expresiones de afecto. Especialmente llama la atención la rosa de plástico sembrada en bolitas de icopor dentro de una caja de plástico transparente.

Como en la serie fotográfica inicial, las expresiones de lo femenino que aparecen en el proceso están revestidas de un carácter de ingenuidad infantil, de cierta idealización naturalista de la belleza. Muchas de estas y de estos jóvenes, no conocían Medellín, entendiendo por esta al centro de la misma y no a su periferia que es donde ellos habitan, no habían caminado por sus calles, no habían conocido un museo o un cine y en esta colección de objetos se ve una significación especial que estos jóvenes aún tienen por las flores, los animales y la vida del campo.

Esta apropiación del mundo es intensa y sutil a la vez, cuenta la historia de jóvenes que están a la expectativa de personas y experiencias estéticas que les ayuden a darle la importancia que tienen estas formas de apropiación del espacio urbano. En cada una de estas expresiones de la ritualidad se hace evidente una marca singular de cada historia de vida, un relato, una narrativa que nos habla del vínculo entre lo sagrado y lo profano. No es posible homogenizar esto desde discursos comerciales o ideales de la ciudad producto o de la ciudad temática. Lo vital y lo que constituye este tipo de ritualidades contemporáneas como prácticas de resistencia es la posibilidad de mantener en la memoria la importancia de la singularidad que construye cada subjetividad durante toda su vida. Estos escenarios hablan de otro tiempo, de uno no productivo, pero que es diferente al tiempo del entretenimiento o el ocio que está permanentemente exigiendo distintos tipos de consumo.

\section{Estéticas rurales en contextos urbanos}

La historia de la planeación urbana de Medellín estuvo influenciada por las perspectivas higienistas francesas de los tres 
últimos decenios del siglo XIX. La medicina fue por supuesto una de las disciplinas más respetadas por las élites locales y trajo consigo el paradigma de la higiene pública como uno de los principales parámetros de progreso y civilización en los ideales de la ciudad moderna. Un acontecimiento particular que ilustra la influencia de los discursos higienistas y de las perspectivas morales impuestas por las elites antioqueñas tiene que ver con la creación de la Policía del Aseo en 1911.

Parafraseando a Escobar (2007), la higiene privada, al estar vinculada con el cuerpo, tocaba también el ámbito de lo moral; esta relación higiene-moral se trasladaba por parte de los nuevos ingenieros higienistas al ámbito de lo público, en donde el perfeccionamiento moral de los habitantes era uno de los principales propósitos de las políticas urbanas, que pretendían producir sanas costumbres ya que sin ellas no podría haber ni progreso ni civilidad. Se establecen desde esta unas relaciones entre higiene - pedagogía e higiene- - vivienda que tendrán una fuerte influencia hasta el día de hoy ${ }^{7}$. Las estrategias dirigidas en este sentido estarían focalizadas en las viviendas obreras y en una permanente preocupación y estigmatización de los barrios no planeados o "barrios de invasión" como focos principales de epidemias físicas y morales. El mejoramiento de las nuevas poblaciones obreras partía de higienizar fisiológica y moralmente a las familias, mejoramiento que generalmente estaba dirigido por preceptos cristianos (Cardona, 2010).
En este sentido fue como de alguna manera la cultura indígena se fue convirtiendo en costumbres campesinas y lo campesino quedó para siempre rotulado con la etiqueta de "pobreza", "miseria" y "suciedad", que se asimila al espacio rural y que además se opone a la lógica del cemento, la limpieza, el aseo, la gentrificación y la perfección que habita la estructura urbana en lo alto de la idealización del progreso.

Esta perspectiva, aunque parece perdida en el tiempo, encontró una aceptación cultural especial en las élites antioqueñas y ha ubicado diversas formas de modularse a través de los años. La ciudad se ha caracterizado por desarrollar diversas estrategias para posicionar la higiene espacial y moral como uno de los valores reguladores relativos a la civilidad. Inicialmente estuvieron ligadas a las empresas de aseo de la ciudad que lanzaron campañas cívicas para mantener la ciudad limpia, en parte de estas nace el apelativo de "La tacita de plata" como es evocada Medellín, que será el referente metonímico como se la reconocerá a nivel nacional. Estas campañas se basan en construir cierta cultura que identifica la limpieza como uno de los valores más preciados de la ciudad.

De hecho, la ciudad oficial, para poder producirse, pone en funcionamiento 3 estrategias: en primer lugar, la estigmatización; en segundo lugar, la demolición, y en tercer lugar, el olvido. La primera estrategia hace posible identificar a ciertos barrios de las "comunas" y a sus habitantes como peligrosos, atrasados o anormales;
Este punto deviene en una biopolitica urbana en la administración de los espacios y los cuerpos en el contexto del capitalis mo. Sobre este punto puede consultarse el libro de Castro-Gómez (2009) sobre capitalismo, movilidad y biopolitica en Bogotá y el artículo de Cardona Rodas y Cardona Arboleda (2016) sobre espacios de exclusión y miradas biopoliticas en Medellín.

territarias 41

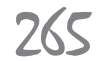


8 "La manifestación de este capitalismo en circulación lo constituye, para Medellín en la primera mitad del siglo XX, el plan piloto de los arquitectos Paul L. Wiener $y$ Luis Sert de 1946, que se concretará en el Plan de Desarrollo Urbanistico de la Ciudad en 1951. Con estos planes se pretendió bacer de la ciudad un centro administrativo asociado a la educación, la seguridad y la cultura (moral capitalista), además de mejorar la circulación vehicular de la ciudad construyendo un sistema vial paralelo al río Medellin. Este sistema vial y el proyecto de una City Planning, propuesta de industrial Ricardo Olano en la segunda década del siglo $X X$, para las ciudades de Medellin y Bogotá, articulando sanidad, planeación urbana, transportes y legislación según la racionalidad de modernidad industrial, sería la antesala de los que desde 1980 se conoce como el Área Metropolitana del Valle de Aburrá, verdadero proyecto de biopolitica urbana que involucra elementos administrativos, económicos $y$ de planeación en un solo complejo urbanistico" (Cardona, 2015, p. 102).

\section{territarias 41}

una vez creado este imaginario e instalado en la cultura "dominante" de los habitantes urbanos se hace evidente la necesidad de la demolición (segunda estrategia) para producir desarrollo. Finalmente, cuando los proyectos urbanos se realizan de modo fragmentario y sin continuidad opera el olvido de las comunidades, de los proyectos iniciados y de las prácticas que ya funcionaban de modo creativo y productivo en estos territorios ${ }^{8}$ (tercera estrategia).

No resulta entonces extraño que lo campesino y lo indígena estén ocultos tras los símbolos de lo urbano y que las personas de manera consciente o inconsciente estén constantemente reviviéndolos en todo espacio donde se aluda a las costumbres. Estos rasgos son las costumbres mismas, sincretizadas en la cotidianidad con el entramado simbólico que obliga a urbanizar el pensamiento, la palabra, la acción y todo sentido estético de la vida. Estos altarcitos en tanto espacios de representación de lo mágico y lo espiritual son a su vez espacios de representación de lo cotidiano y lugares de la memoria onírica o de tiempos pasados previos al tiempo de quien los habita, que dan cuenta de la historia de los pueblos y dotan de sentido a las costumbres que interpelan.

\section{Conclusiones}

El universo simbólico de las personas que habitan la comuna 3 de Medellín, específicamente el barrio Bello Oriente, está constituido por pequeños altares que dan cuenta de una hibridación entre las costumbres campesinas antioqueñas de antaño y los elementos contemporáneos que la urbe invita a disfrutar y tomar para sí.

La manera en que disponen algunos elementos cotidianos a manera de altar permite entender mejor la relación que tienen algunos artilugios con sus costumbres y propicia reflexiones interesantes en el marco de las transformaciones que se viven en Medellín, en tanto ciudad que se ha encaminado en el desarrollo territorial que deviene en segregaciones socioespaciales. Basta una mirada rápida de las estéticas de las periferias de la ciudad en el interior de sus casas para darse cuenta del contraste que implica la lógica del concreto y del cemento que se ha venido imponiendo como modelo estético obligatorio para toda la urbe. Se evidencia de esta manera la relación existente entre la estética doméstica y los universos simbólicos de quienes habitan la ciudad.

La ciudad se habita como superposición de varias imágenes o de muchos componentes, está construida de símbolos y miles de huellas del poblamiento, la geografía, los cementerios, las calles, los parques, la gente, los grafitis. La ciudad es un espejo que devuelve nuestro narciso, donde las relaciones entre las cosas que coexisten en la ciudad serían como un alfabeto de un lenguaje que sirve para formar palabras y frases.

Podemos observar en el análisis específico de estas estéticas rururbanas los distintos modos como los habitantes de estos territorios han vivido, sobrevivido $\mathrm{y}$ 
reconstruido los imaginarios oficiales de ciudad. Es precisamente en estas representaciones visibles, fasmas ${ }^{9}$ en la serie fotográfica presentada, donde se reconocen las prácticas de hibridación y creatividad que han construido de modo lento y procesual prácticas que muchas veces han sido estigmatizadas por la "sociedad civilizada" del centro de la ciudad, que las asimila como peligrosas, antihigiénicas, miserables o subdesarrolladas. Pero lo que se expone es la manifiestación de una carga simbólica de apropiación de espacios concretos en el contexto bipolítico urbano de Medellín.

El rasgo especial de las fotografías que integran este artículo radica en que las narrativas de estas historias personales y familiares se develan en nuevas ritualidades, en las cuales los objetos de la cultura de masas son resignificados y combinados con íconos religiosos tradicionales que constituyen una emergencia de la religiosidad rururbana en el barrio Bello Oriente. Un hibrido que representa el presente y el pasado y da cuenta tanto del universo físico que habitan, como del simbólico que los habita desde donde se reconoce un proceso de resistencia creativa proyectado en expresiones artísticas de las costumbres y las prácticas del habitar.

Frente a las estrategias de Medellín para constituirse en ciudad, esta serie fotográfica aparece como una práctica de libertad, una respuesta que si bien puede parecer precaria, tiene la fuerza de actualizar en el presente las vidas de estos pobladores que también construyen lo urbano desde sus apropiaciones estéticas rurales. Los argumentos que pueden esgrimirse ante esta posible percepción, es que en Medellín no existe un registro que deje memoria de estas otras ciudades que la habitan y que también son Medellín, es decir, que también la constituyen, por lo cual estas fotografías y lo que aquí se dice permiten que las comunidades construyan la memoria de sus trayectos o al menos hagan un recuento de los caminos transitados para llegar al universo simbólico que habitan.

Con base en estas observaciones se puede inferir con facilidad que se presenta la misma estructura simbólica que ya se ha identificado como sistema estético, presente entre la estética chicana y el proceso ritual cotidiano, que sacraliza los espacios en Medellín y da cuenta de elementos importantes de las costumbres arraigadas que podrían difuminarse con facilidad frente a elementos nuevos que llegan a establecerse en la idiosincrasia de los grupos. Igualmente es posible entender las dinámicas de exclusión-inclusión social que se generan a partir de la consolidación de una estética estática que desconoce los universos simbólicos que le dan sentido a la vida de los habitantes de esta ciudad, lo cual pude derivar en una reflexión con posibilidades de expansión en un derecho a la ciudad habitada, morada, transitada, apropiada y resignificada: ¿qué función tiene para los habitantes de las ciudades el sentido estético de sus universos simbólicos y cómo esto influye en la relación que establecen con la administración de las urbes que les cobijan si estas últimas
9 Una aparición que palpita en el aleteo del movimiento de la imagen ante el vértigo de la revelación del sintoma en apertura estética (Didi-Huberman, 2015; Benjamin, 2013). territarias 41

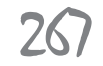


no legitiman ni reconocen dichas estéticas a la hora de expandirse y reinventarse?

\section{Referencias}

Bauman, Z. (1999). Modernidad líquida. Buenos Aires: Fondo de Cultura Económica.

Benjamin, W. (2013). Tesis sobre la historia $u$ otros fragmentos. Bogotá: Ediciones Desde Abajo.

Cardona Rodas, H. (2010). Espacios de vigilancia y de familiaridad disciplinaria. Barrios obreros en Medellín (19001925). En V. Espinal \& C. Flórez López (Comps.), Izquierda y derecha. Discursos y actores de la politica contemporánea (pp. 243-256). Medellín: Universidad de Medellín.

Cardona Rodas, H. (2015). Dinámicas biopolíticas en el entramado urbano de la ciudad de Medellín y municipios aledaños entre 1945 y 1951. Anuario de Antropología Social y Cultural en Uruguay, 13, 91-104.

Cardona Rodas, H., \& Cardona Arboleda, J. D. (2016). Heterotopías urbanas. Espacios de la exclusión y miradas biopolíticas de Medellín en el siglo Xx. Ciencias Sociales y Educación, 5(9), 81-104.

Castaingts, J. (2002). Simbolismos del dinero. Antropología y economia: una encrucijada. Barcelona: Anthropos Editorial.

Castro-Gómez, S. (2009). Tejidos oníricos: movilidad, capitalismo y biopolitica en

\section{territarias 41} Bogotá (1910-1930). Bogotá: Editorial Pontificia Universidad Javeriana.
Deleuze, G., \& Guattari, F. (2004). Mil mesetas. Capitalismo y esquizofrenia. Valencia: Pre-Textos.

Delgado, M. (1999). El animal público. Barcelona: Anagrama.

Didi-Huberman, G. (2015). Fasmas. Enayos sobre la aparición 1. Santander-Cantabria: Editorial Shangriila.

Durand, G. (1971). La imaginación simbólica. Buenos Aires: Amorrortu.

Real Academia Española. (1992). Diccionario de la Lengua Española, entrada Chicano. Madrid: Editorial Espasa Calpe.

Escobar, A. (2007). La invención del tercer mundo. Construcción y deconstrucción del desarrollo. Caracas: Editorial el perro y la rana.

García Canclini, N. (1990). Culturas híbridas. Estrategias para entrar y salir de la modernidad. México: Grijalbo.

Geertz, C. (2003). La interpretación de las culturas. Barcelona: Gedisa.

Jung, C. G. (1976). Lo inconsciente. Buenos Aires: Losada.

Grau-Solés, M., Íñiguez-Rueda, L., \& Subirats, J. (2012). Una perspectiva híbrida y no-moderna para los estudios urbanos. Athenea Digital. Revista de Pensamiento e Investigación Social, 12(1), 89108. Doi: https://doi.org/10.5565/ $\mathrm{rev} / \mathrm{athenead} / \mathrm{v} 12 \mathrm{nl} 1.910$

Kandinsky, W. (1989). De lo espiritual en el arte. Tlahuapan: Premia Editores.

Kartofel, G. (1985). Acerca de las artes plásticas de los chicanos. Revista Mascarones, (5), 16-19. 
Lévi-Strauss, C. (1997). El pensamiento salvaje. México D. F.: Fondo de Cultura Económica.

Palmett Plata, O. (2015). Transformaciones conceptuales del paisaje urbano de Medellín. Investigaciones Geográfica, 50, 105-122.

Paz, O. (1985). El laberinto de la soledad. México D. F.: Fondo de Cultura Económica.

Solares, B. (2008). Apuntes para una hermenéutica de la imagen. En P.F. Lazo Briones (Comp.), Ética, hermenéutica $y$ multiculturalismo (pp. 111-116).
México D. F.: Universidad Iberoamericana.

Solares, B. (2011). Gilbert Durand, imagen y símbolo o hacia un nuevo espíritu antropológico. Revista Mexicana de Ciencias Politicas y Sociales, LVI(211), 13-24.

Soto, E. (2003). La cultura chicana, ¿manifestación cultural, rebelión o protesta? Reencuentro, 37, 39-42.

Tatarkiewicz, W. (2015). Historia de seis ideas. Arte, belleza, forma, creatividad, mimesis, experiencia estética. Madrid: Tecnos. 
